\title{
Endogenous Surfactant Turnover in Preterm Infants Measured with Stable Isotopes
}

\author{
JAN ERIK H. BUNT, LUC J. ZIMMERMANN, J. L. DARCOS WATTIMENA, RON H. van BEEK, \\ PIETER J. SAUER, and VIRGILIO P. CARNIELLI
}

Department of Pediatrics, Division of Neonatology, Sophia Children's Hospital, University Hospital Rotterdam, Erasmus University Rotterdam, Rotterdam, The Netherlands

\begin{abstract}
We studied surfactant synthesis and turnover in vivo in preterm infants using the stable isotope $\left[\mathrm{U}-{ }^{13} \mathrm{C}\right] \mathrm{glucose}$, as a precursor for the synthesis of palmitic acid in surfactant phosphatidylcholine (PC). Six preterm infants (birth weight, $916 \pm 244$ g; gestational age, $27.7 \pm 1.7$ wk) received a 24-h $\left[\mathrm{U}-{ }^{13} \mathrm{C}\right]$ glucose infusion on the first day of life. The ${ }^{13} \mathrm{C}$-enrichment of palmitic acid in surfactant PC, obtained from tracheal aspirates, was measured by gas chromatography-combustion interface-isotope ratio mass spectrometry. We observed a significant incorporation of carbon-13 from glucose into surfactant PC palmitate. PC palmitate became enriched after $19.4 \pm 2.3$ (16.5 to 22.3) $\mathrm{h}$ and reached maximum enrichment at $70 \pm 18$ (48 to 96) $\mathrm{h}$ after the start of the label infusion. The fractional synthesis rate (FSR) of surfactant PC palmitate from glucose was $2.7 \pm 1.3 \% / \mathrm{d}$. We calculated the absolute production rate of surfactant PC to be $4.2 \mathrm{mg} / \mathrm{kg} / \mathrm{d}$, and the half-life to be $113 \pm 25$ (87 to 144$) ~ h$. Data on endogenous surfactant production and turnover were obtained for the first time in human infants with the use of stable isotopes. This novel and safe method could be applied to address many important issues concerning surfactant metabolism in preterm infants, children, and adults. Bunt JEH, Zimmermann LJ, Wattimena JLD, van Beek RH, Sauer PJ, Carnielli VP. Endogenous surfactant turnover in preterm infants measured with stable isotopes.
\end{abstract}

AM J RESPIR CRIT CARE MED 1998;157:810-814.

Pulmonary surfactant deficiency is the main cause of respiratory distress syndrome (RDS) in the preterm infant (1). Prenatal administration of corticosteroids and postnatal treatment with exogenous surfactant have greatly reduced morbidity and mortality caused by RDS $(2,3)$. However, some infants respond poorly or only temporarily to surfactant therapy. Different clinical responses to exogenous surfactant could reflect differences in surfactant metabolism between individuals. To date, surfactant analysis of sequential tracheal aspirates is the only available method for the evaluation of surfactant production in humans $(4,5)$. A Ithough this method provides data on the quality and concentration of surfactant, it does not give information on the endogenous production and catabolism. In animals, the synthesis and catabolism of surfactant are measured with radioactive tracers (6-9). This approach is not acceptable in humans, and especially not in infants. We studied endogenous surfactant production and turnover in preterm infants with RDS, using a novel and safe method. We used the stable isotope $\left[U-{ }^{13} \mathrm{C}\right.$ ]glucose as a precursor for the fatty acid synthesis of lung phosphatidylcholine (PC). We measured car-

(Received in original form December 10, 1996 and in revised form October 31 1997)

Supported by The Sophia Foundation for Medical Research.

Correspondence and requests for reprints should be addressed to Luc J. Zimmermann, M.D., Ph.D., Neonatology, Sophia Children's Hospital, Dr Molewaterplein 60, 3015 GJ Rotterdam, The Netherlands.

Am J Respir Crit Care Med Vol 157. pp 810-814, 1998 bon-13 incorporation into the fatty acids of surfactant PC obtained from tracheal aspirates of preterm infants with R DS.

\section{METHODS}

\section{Patients and Study Design}

Six premature infants requiring mechanical ventilation were studied (birth weight, $916 \pm 244 \mathrm{~g}$; gestational age, $27.7 \pm 1.7 \mathrm{wk}$ ) (Table 1), starting directly after birth. Inclusion criteria were: gestational age $<31$ wk, prenatal corticosteroid therapy, severe RDS on chest radiograph (G iedeon Grade III-IV), and written parental informed consent. Exclusion criteria were: congenital infection, maternal diabetes, and chromosomal abnormality. Patients received a constant intravenous infusion of $\left[\mathrm{U}-{ }^{13} \mathrm{C}\right.$ ]glucose (Campro Scientific, V eenendaal, The $\mathrm{N}$ etherlands) for $24 \mathrm{~h}$ at $0.170 \mathrm{mg} / \mathrm{kg} / \mathrm{min}$. The start of the study ( $\mathrm{t}=$ 0 ) was defined by the start of the infusion of the labeled glucose. This was $4.2 \pm 1.1 \mathrm{~h}$ after birth. The labeled glucose was infused by a high precision pump (M 22; H arvard A pparatus Co. Inc., South Natick, $\mathrm{MA}$ ). The total glucose intake was $5.7 \mathrm{mg} / \mathrm{kg} / \mathrm{min}$, including nonlabeled glucose. B efore and during the glucose infusion, $1.0 \mathrm{ml}$ arterial blood was drawn every $6 \mathrm{~h}$ for determination of glucose enrichment. Exogenous surfactant (Survanta; A bbott Laboratories, N orth Chicago, $\mathrm{IL}$ ) was administered endotracheally at $\mathrm{t}=0$, at a dose of $100 \mathrm{mg} / \mathrm{kg}$ phospholipids, if the mean airway pressure exceeded $7.5 \mathrm{~cm}$ of water, or if the inspiratory oxygen fraction $\left(\mathrm{Fl}_{\mathrm{O}_{2}}\right)$ was higher than 0.40 . Infants received a second dose $6 \mathrm{~h}$ later if the criteria were still met. Tracheal aspirates were obtained every $6 \mathrm{~h}$ during the time that the infant was intubated. The tracheal suctioning procedure was performed during routine patient care and did not deviate from the normal clinical protocol. T wenty seconds after $0.5 \mathrm{ml}$ normal saline was injected into the tracheal tube, suction was done beyond the tip of the endotracheal tube. The suction catheter was flushed with normal saline. Tracheal 
TABLE 1

CHARACTERISTICS OF THE PATIENTS BEFORE AND DURING THE STUDY

\begin{tabular}{|c|c|c|c|c|c|c|c|c|c|c|}
\hline Patient No. & $\begin{array}{l}\text { Gestational Age } \\
\text { (wk) }\end{array}$ & $\begin{array}{c}\text { Birth Weight } \\
(\mathrm{g})\end{array}$ & RDS Grade & $\begin{array}{l}\text { Doses of } \\
\text { Surfactant } \\
\text { (n) }\end{array}$ & $\begin{array}{l}\text { Apgar at } \\
5 \mathrm{Min}\end{array}$ & Umbilical pH & $\begin{array}{c}\mathrm{Fl}_{\mathrm{O}_{2}} \text { at } \\
\mathrm{t}=24 \mathrm{~h}\end{array}$ & $\begin{array}{c}\mathrm{Fl}_{\mathrm{O}_{2}} \text { at } \\
\mathrm{t}=36 \mathrm{~h}\end{array}$ & $\begin{array}{c}\mathrm{Fl}_{\mathrm{O}_{2}} \text { at } \\
\mathrm{t}=48 \mathrm{~h}\end{array}$ & $\begin{array}{l}\text { Days of } \\
\text { Intubation } \\
\text { (n) }\end{array}$ \\
\hline 1 & 27.1 & 1,140 & IV & 2 & 9 & 7.30 & 0.26 & 0.25 & 0.23 & 15.0 \\
\hline 2 & 27.7 & 840 & IV & 1 & 7 & 7.30 & 0.21 & 0.21 & 0.21 & 2.0 \\
\hline 3 & 29.1 & 770 & IV & 2 & 8 & 7.17 & 0.26 & 0.35 & 0.30 & 22.0 \\
\hline 4 & 26.1 & 900 & III & 2 & 8 & 7.30 & 0.35 & 0.34 & 0.34 & 12.5 \\
\hline 5 & 30.3 & 1,255 & IV & 2 & 6 & 6.95 & 0.40 & 0.37 & 0.35 & 5.6 \\
\hline 6 & 25.6 & 590 & III & 2 & 6 & - & 0.40 & 0.44 & 0.35 & 31.0 \\
\hline Mean & 27.7 & 916 & - & - & 7.3 & 7.21 & 0.31 & 0.33 & 0.30 & 14.7 \\
\hline SD & 1.7 & 244 & - & - & 1.2 & 0.15 & 0.08 & 0.08 & 0.06 & 10.7 \\
\hline
\end{tabular}

Definition of abbreviations: RDS = respiratory distress syndrome; $\mathrm{F}_{\mathrm{O}_{2}}=$ fraction of inspired oxygen content.

aspirates were immediately placed at $-20^{\circ} \mathrm{C}$, until further processing. $\mathrm{N} o$ tracheal suction was done within $6 \mathrm{~h}$ after surfactant administration. Total parenteral nutrition, including lipids, was started at $t=48 \mathrm{~h}$. The study was approved by the local medical ethics committee.

\section{Analytical Procedure}

Tracheal aspirates. A fter thawing, normal saline was added to the aspirate. This was vortexed and centrifuged at $450 \times \mathrm{g}$ for $10 \mathrm{~min}$ at $4^{\circ} \mathrm{C}$ (10); lipids were extracted from the supernatant (11). Surfactant PC was isolated from the lipid extract by thin layer chromatography (TLC) (12) using K ieselgel 60 TLC plates (M erck, Darmstadt, Germany) and a Canag L inomat IV (M erck, D armstadt, Germany). The PC was derivatized (13), and the fatty acid methyl esters were extracted with hexane and stored at $-20^{\circ} \mathrm{C}$. Tracheal aspirates containing visible blood were not analyzed.

Blood samples. Blood was collected from the patient in lithiumheparin-containing vacutainers and directly centrifuged to separate plasma and cells. The plasma was stored at $-70^{\circ} \mathrm{C}$ until further processing. Plasma was delipidated with chloroform and methanol (14). The water fraction was passed over a column with anion-exchange resin (A G - 1X 8 [acetate], 100-200 mesh; BioR ad L aboratories, R ichmond, CA ) and cation-exchange resin (A G -50W X 8 [hydrogen], 200400 mesh; BioR ad). The elute containing the glucose was evaporated to dryness at $80^{\circ} \mathrm{C}$ and derivatized to an aldonitril pentacetate derivative (15).

\section{Determination of Enrichment}

The enrichment of selected fatty acids, components of surfactant PC, and of plasma glucose was measured by gas chromatography-combustion interface-isotope ratio mass spectrometry (GC-CI-IRMS) (VG I sotech, M idlewich, Cheshire, UK) as previously described (16). For fatty acid analysis, $1 \mu \mathrm{l}$ was injected on column ( $30 \mathrm{~m}$ O megawax column; Supelco, $Z$ wijndrecht, The N etherlands). The injection and oven temperature was $45^{\circ} \mathrm{C}$ for $2 \mathrm{~min}$ and raised at $15^{\circ} \mathrm{C} / \mathrm{min}$ to $175^{\circ} \mathrm{C}$, held for $15 \mathrm{~min}$ at $175^{\circ} \mathrm{C}$, and subsequently ramped with $2^{\circ} \mathrm{C} / \mathrm{min}$ to $240^{\circ} \mathrm{C}$. For glucose, $1 \mu \mathrm{l}$ was injected on a $25 \mathrm{~m} \times 0.25 \mathrm{~mm}, 0.11 \mu \mathrm{m}$ H T-5 capillary column (Scientific G lass Engineering, Victoria, A ustralia), with a split ratio of 30:1. The oven temperature was isothermal at $220^{\circ} \mathrm{C}$. The enrichment was expressed in atom percent excess (A PE), which represents the increase in the percentage of carbon-13 atoms in total carbon dioxide from the combusted compounds above baseline enrichment (before infusion). Enrichments were corrected for the contribution of unlabeled carbon atoms added during derivatization.

\section{Calculations}

Tissue-bound and alveolar surfactant were regarded as one pool since studies in newborn rabbits showed that recycling is $\sim 16$ times faster than the de novo synthesis and clearance (7-9). A s palmitic acid is by far the most abundant fatty acid in surfactant PC, calculations were performed for palmitic acid only. $\mathrm{D}$ ata are presented as mean \pm standard deviation (range).

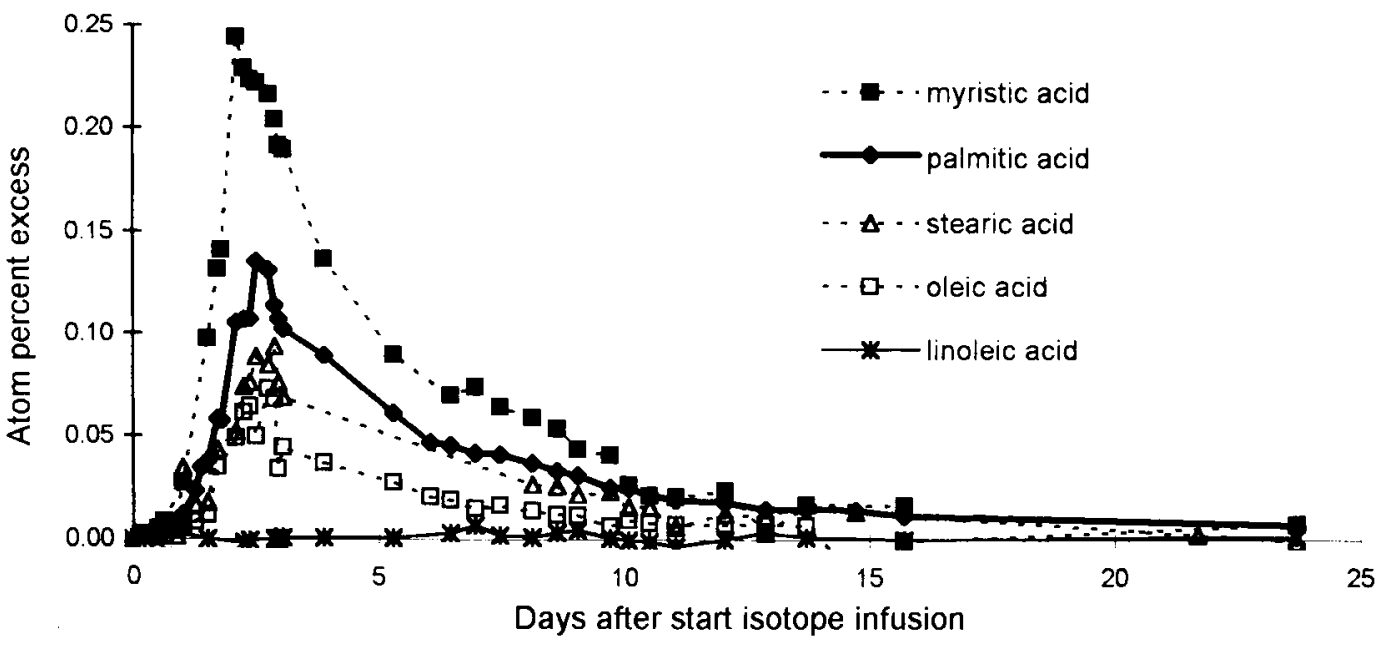

Figure 1. ${ }^{13} \mathrm{C}$-enrichment of selected fatty acids of surfactant phosphatidylcholine in Patient 3. At admis sion, ventilated preterm infants received a $24-\mathrm{h}\left[\mathrm{U}-{ }^{13} \mathrm{C}\right]$ glucose infusion. During the period that the infant was intubated, tracheal aspirates were obtained and surfactant phosphatidylcholine (PC) was isolated. ${ }^{13} \mathrm{C}$-enrichment of the different fatty acids in surfactant PC was measured and expressed in atom percent excess (APE). 
Secretion time was defined as the time lag between the start of the $\left[\mathrm{U}-{ }^{13} \mathrm{C}\right]$ glucose infusion and the appearance of enriched fatty acids in surfactant PC. The time of appearance of the enrichment in PC palmitate was calculated by plotting the regression line for the linear-increasing part of the enrichment versus time curve, and extrapolating it to baseline enrichment (I7).

F ractional synthesis rate (FSR) of palmitic acid is expressed as the percentage of the total surfactant PC palmitate pool synthesized from glucose per day. It is calculated by dividing the slope of the linear increase of enrichment of PC palmitate by the steady-state enrichment of plasma glucose (18).

$\mathrm{H}$ alf-life of PC palmitate was calculated by exponential curve-fitting at the final, monoexponential part of the downslope of the enrichment versus time curve.

\section{RESULTS}

The patients' characteristics are shown in Table 1. Patients received two doses of exogenous surfactant, except for Patient 2 who received one dose and was extubated on the second day of life. Exogenous surfactant therapy resulted in a decrease of the $\mathrm{F}_{\mathrm{O}_{2}}$ from $0.53 \pm 0.18$ to $0.25 \pm 0.06$. In Patient 6 , the $\mathrm{Fl}_{\mathrm{O}_{2}}$ decreased after the first dose of surfactant, from 0.50 to 0.25 , but it increased again to 0.40 , and a second dose did not result in a decrease in oxygen need.

The ${ }^{13} \mathrm{C}$-enrichment of plasma glucose reached a steady state of $2.63 \pm 0.45 \mathrm{APE}$ in all patients between $\mathrm{t}=6$ and $\mathrm{t}=$ $24 \mathrm{~h}$ (data not shown). This was concluded because the slope of the enrichment versus time curve per patient did not deviate significantly from zero in this period.

The ${ }^{13} \mathrm{C}$-enrichments of selected fatty acids in $\mathrm{PC}$ in Patient 3 are shown in Figure 1. The enrichment versus time curves of the nonessential fatty acids showed the same pattern. A s expected, the essential fatty acids were not enriched (only linoleic acid is depicted in Figure 1 ).

The increasing enrichment of PC palmitate for all patient is shown in Figure 2. The regression line of the linear part was used for calculating the secretion time, which was $19.4 \pm 2.3$ (16.5 to 22.3) h (Table 2), and for calculating the fractional

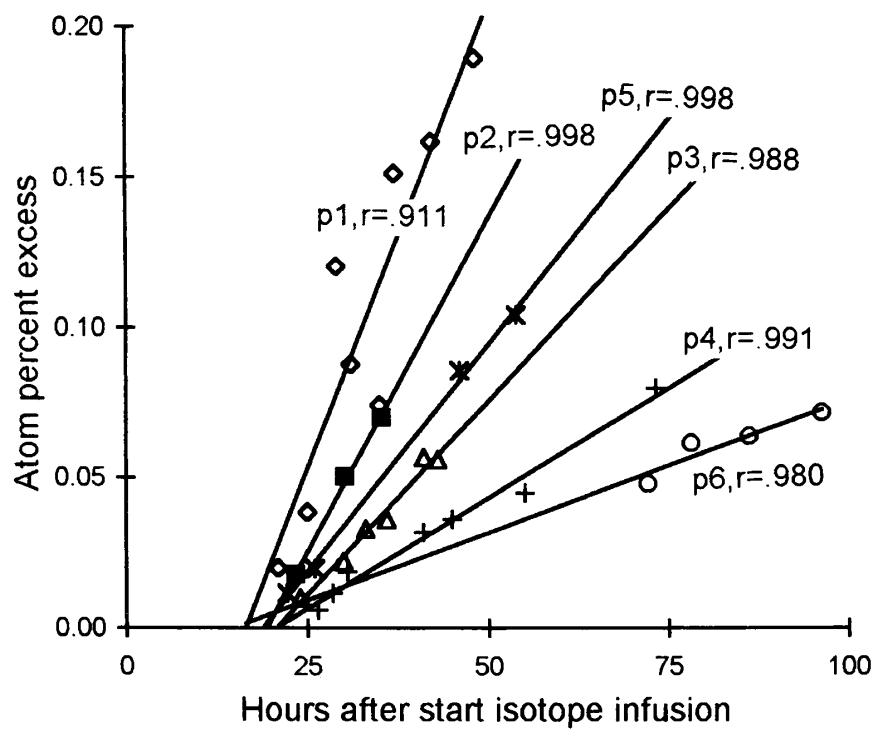

Figure 2. Linear increase in ${ }^{13} \mathrm{C}$-enrichment of palmitic acid in surfactant phosphatidylcholine in each patient. The regression line for each patient is shown. For calculation of secretion time, the regression line was extrapolated to baseline enrichment. The fractional synthesis rate was calculated by dividing the slope of the regression line by steady-state enrichment of plasma glucose.
TABLE 2

KINETICS OF PALMITIC ACID IN SURFACTANT PHOSPHATIDYLCHOLINE*

\begin{tabular}{lcccc}
\hline & $\begin{array}{c}\text { Secretion } \\
\text { Time } \\
(\mathrm{h})\end{array}$ & $\begin{array}{c}\text { FSR } \\
(\% / \mathrm{d})\end{array}$ & $\begin{array}{c}\text { Maximal Enrichment after } \\
\text { Start of }\left[\mathrm{U}-{ }^{13} \mathrm{C}\right] \text { Glucose }(\mathrm{h})\end{array}$ & $\begin{array}{c}\text { Half-life } \\
(\mathrm{h})\end{array}$ \\
\hline Patient No. & 16.5 & 4.25 & 48 & 144 \\
2 & 20.0 & 4.07 & - & - \\
3 & 21.6 & 2.28 & 60 & 97.6 \\
4 & 22.3 & 1.40 & 73 & 86.6 \\
5 & 18.9 & 3.14 & 74 & 105 \\
6 & 17.4 & 1.06 & 96 & 133 \\
Mean & 19.4 & 2.70 & 70 & 113 \\
SD & 2.3 & 1.34 & 18 & 24.5 \\
\hline
\end{tabular}

Definition of abbreviation: $\mathrm{FSR}$ = fractional synthesis rate.

* Six ventilated preterm infants received a $24-h\left[U^{13} \mathrm{C}\right] g$ lucose infusion. During the period the infants were intubated, tracheal aspirates were obtained and surfactant phosphatidylcholine (PC) was isolated. Enrichment of palmitic acid in PC was measured and expressed in atom percent excess. Kinetic parameters were calculated using enrichment versus time curves from plasma glucose and surfactant PC palmitate.

synthesis rate. The FSR of PC palmitate from glucose was $2.7 \pm$ $1.3 \%$ ( 1.06 to $4.25 \%$ ) per day. M aximal enrichment was reached at $70 \pm 18$ ( 48 to 96) h. D ecreasing enrichment of palmitic acid in $P C$ in each individual patient is shown in Figure 3. The marks are shown for one patient only. The closed marks represent the monoexponential part used for half-life calculations. The half-life of endogenous synthesized surfactant PC palmitate was $113 \pm 25$ (87 to 144$) \mathrm{h}$.

\section{DISCUSSION}

This study measures for the first time endogenous surfactant production and turnover in humans. We infused the stable iso-

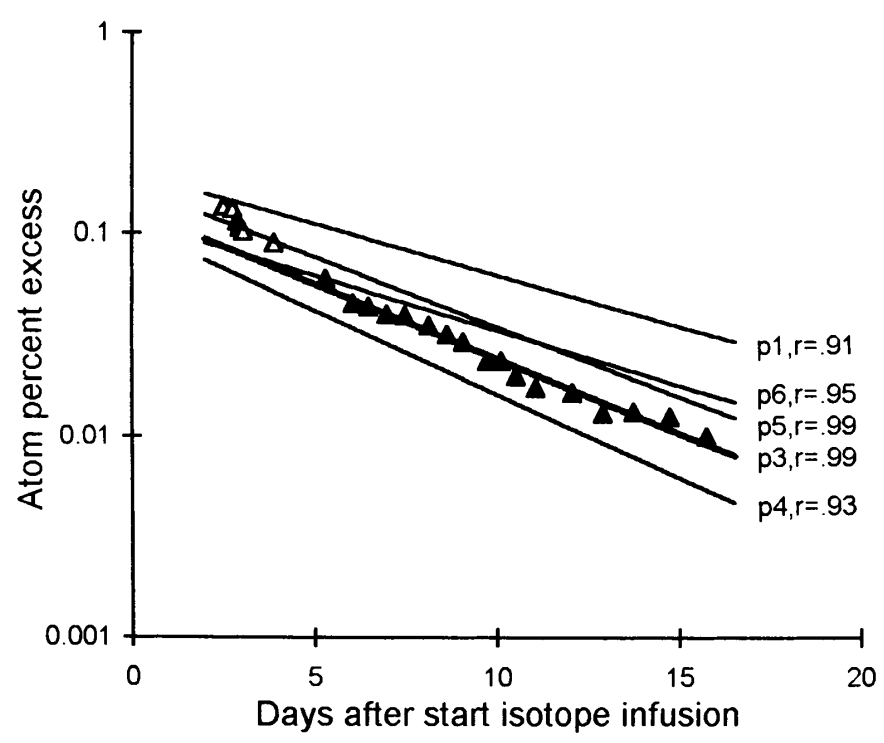

Figure 3. Decrease of ${ }^{13} \mathrm{C}$-enrichment of palmitic acid in surfactant phosphatidylcholine for each patient separately, represented by the corresponding regression lines. The regression line of Patient 2 is not shown because the patient was extubated on Day 2 of life. For clarity, the individual marks are shown for one patient only. The open symbols represent the start of the decreasing enrichment. The closed symbols from the same patient show the final monoexponential decrease, which was used to calculate half-life. The half-lives are calculated from the final part of the curve to minimize the effect of possible ${ }^{13} \mathrm{C}$-palmitic acid incorporation from plasma. 
tope $\left[\mathrm{U}-{ }^{13} \mathrm{C}\right.$ ]glucose in preterm infants and measured the ${ }^{13} \mathrm{C}$ enrichment of selected fatty acids in surfactant PC. The incorporation of the carbon-13 into surfactant PC palmitate began at $19.4 \pm 2.3$ ( 16.5 to 22.3 ) $\mathrm{h}$ after the start of the isotope infusion (Figure 2), which likely corresponds to the time required for palmitic acid synthesis from glucose, processing of surfactant PC in the alveolar type II cell, and secretion into the alveolar spaces. In preterm ventilated lambs that received an intravenous injection of $\left[{ }^{3} \mathrm{H}\right]$ palmitic acid, radioactivity was al ready detected in surfactant after $5 \mathrm{~h}$ (9). This suggests that incorporation of plasma palmitate into surfactant PC is a faster process than palmitic acid synthesis from glucose with subsequent incorporation into surfactant PC. In our study, the PC palmitate enrichment was maximal at $70 \pm 18$ (48 to 96) $h$ after the start of the isotope infusion. This time-to-peak enrichment is dependent on the duration of the isotope infusion (24 h) among other factors. The maximal enrichment was found at $46 \pm 18 \mathrm{~h}$ after the finish of the isotope infusion (Figure 1), which is comparable to the 35 to $60 \mathrm{~h}$ found in newborn rabbits and lambs after a single intravenous bolus of radiolabeled palmitic acid $(9,19,20)$.

In our study we found a half-life of $4.7 \pm 1.0$ (3.6 to 6.0 ) d, which indicates that in human preterm infants endogenous surfactant remains in the lung for a long time. To minimize the potential influence of ongoing incorporation of labeled palmitic acid produced via lipogenesis in the liver, we calculated half-life from the final monoexponential part of the enrichment versus time curve. To confirm that there is no major influence of ongoing incorporation from labeled palmitic acid during the time frame of half-life calculation, we measured enrichment of palmitic acid in plasma triglycerides and phospholipids in three patients who were clinically comparable to the study patients. The enrichment of palmitic acid in plasma triglycerides and phospholipids was maximal at $\mathrm{t}=25 \pm 0 \mathrm{~h}$ $(0.22 \pm 0.01 \mathrm{~A} \mathrm{PE})$ and $35 \pm 5 \mathrm{~h}(0.16 \pm 0.01 \mathrm{APE})$, respectively, and decreased afterwards. The enrichment of plasma-free palmitic acid was measured in one patient and was very low during the entire study period (maximal at $t=24 \mathrm{~h}, 0.05 \mathrm{APE}$, and at $t=70 \mathrm{~h}, 0.01 \mathrm{APE}$ ). A t the time of maximal enrichment of surfactant PC palmitic acid $(t=70 \mathrm{~h}, 0.12 \pm 0.047$ $\mathrm{A} P \mathrm{PE}$ ) the enrichment of triglycerides was $0.020 \pm 0.01 \mathrm{APE}$ and that of phospholipids was $0.02 \pm 0.002 \mathrm{~A} \mathrm{PE}$. D uring the period of half-life calculation (starting from approximately $100 \mathrm{~h}$ ), the enrichment of surfactant PC palmitate was $0.09 \pm$ $0.03 \mathrm{~A} \mathrm{PE}$. The ${ }^{13} \mathrm{C}$-enrichment of palmitic acid in triglycerides and phospholipids was much lower $(0.01 \pm 0.01$ and $0.020 \pm$ $0.01 \mathrm{~A}$ PE, respectively). This indicates that the long half-life for surfactant PC palmitate is not due to the presence of a high enrichment of plasma palmitic acid but a reflection of surfactant PC metabolism in the lungs. The long half-life of $4.7 \mathrm{~d}$ of surfactant PC in our study is compatible with findings in animal studies. In term newborn sheep, after tracheal instillation of PC labeled with $\left[^{3} \mathrm{H}\right.$ ]palmitic acid the half-life of PC in the alveolar wash was approximately $11.6 \mathrm{~d}$ (21). In term newborn rabbits, who received a bolus of albumin-bound $\left[{ }^{3} \mathrm{H}\right.$ ]palmitic acid intravenously, the specific activity of alveolar PC $\left[{ }^{3} \mathrm{H}\right]$ palmitate had a half-life ranging from $>2$ to $5.7 \mathrm{~d}$ $(9,22)$. In one study using surfactant labeled with $\left[{ }^{14} \mathrm{C}\right] \mathrm{D}$ P PC

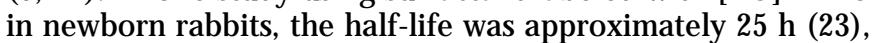
which is shorter than in most other studies, possibly explained by the short duration of this study (only $16 \mathrm{~h}$ ). Support of a long half-life of surfactant in human preterm infants is provided by a study by $\mathrm{H}$ allman and colleagues (5) who reported that PC concentrations in tracheal aspirates after surfactant administration in preterm infants with RDS did not decrease during the first week of life. In preterm infants with RDS treated with surfactant containing phosphatidylglycerol, the half-life of phosphatidylglycerol in tracheal aspirates was calculated by $\mathrm{H}$ allman and colleagues (4) to be 20 to $36 \mathrm{~h}$. This might be different, however, from the half-life of PC, as it is known that not all surfactant components have the same turnover rates.

In our study all infants received exogenous surfactant, which readily mixes with the endogenous pool. Whether exogenous surfactant influences endogenous surfactant metabolism and whether the half-life of exogenous surfactant is similar remains to be studied.

In our study the rate of PC palmitate synthesis from glucose was low ( $F S R=2.7 \% / d$ ), which could partially explain why preterm infants with RDS who do not receive exogenous surfactant improve only after a few days. Thus the only way to rapidly augment the surfactant pool in newborns with $R D S$ is by exogenous surfactant administration. The pool size of endogenous PC in preterm infants with RD S is very low and estimated to be approximately $5 \mathrm{mg} / \mathrm{kg}(4,24)$. Therefore, we assumed the total lung surfactant PC pool size to be the estimated endogenous pool size $(5 \mathrm{mg} / \mathrm{kg}$ ) together with the administered dose of exogenous surfactant, $87 \mathrm{mg} / \mathrm{kg} \mathrm{PC}$ after one dose or $174 \mathrm{mg} / \mathrm{kg} \mathrm{PC}$ after two doses. With this assumption, we calculated the production rate of $P C$ palmitate from glucose to be $2.2 \pm 1.1$ (0.99 to 3.95$) \mathrm{mg} / \mathrm{kg} / \mathrm{d}$. This corresponds to a PC production rate from glucose of approximately $4.2 \mathrm{mg} /$ $\mathrm{kg} / \mathrm{d}$ (absolute production rate $=\mathrm{FSR} \times$ pool size). It is possible, however, that part of the exogenous surfactant is not completely retained within the lungs, which would result in an overestimation of pool size and surfactant PC synthesis. In newborn rabbits and in preterm monkeys surfactant production from palmitic acid and choline was estimated to be 8.4 and $12.5 \mathrm{mg} / \mathrm{kg} / \mathrm{d}$, respectively, when measured with labeled choline and palmitic acid $(9,25)$. The absolute production rate in our study was slightly lower than that in the animal studies mentioned above, possibly because we calculated production from glucose only. The low production rate indicates that only after several days a considerable amount of surfactant is present in the alveolus. This observation is in agreement with the study of $\mathrm{H}$ allman and colleagues (5), which showed that after 4 to $5 \mathrm{~d}$ the concentration of $\mathrm{PC}$ in the alveolus reaches values comparable to preterm infants without $R D S$.

In the type II pneumocyte, glucose is a primary source for fatty acid synthesis of surfactant PC (26-28). In the type II cell other substrates are used for surfactant PC palmitate synthesis as well, such as fatty acids derived from lipolysis (27), lactate, pyruvate, and ketone bodies (26). We measured endogenous PC palmitate synthesis from glucose only. We have recently demonstrated that lipogenesis from glucose occurs in preterm infants fed solely glucose intravenously on the first day of life (29). Therefore, with our approach carbon-13 incorporation into surfactant PC occurs via lipogenesis in type II cells directly or via lipogenesis in the liver and subsequent uptake of labeled palmitic acid by type II cells.

In summary, this study shows that in preterm infants with RDS, after prenatal corticosteroid therapy and postnatal surfactant administration, the surfactant PC palmitate production from glucose is a slow process. The long half-life of $4.7 \mathrm{~d}$ indicates also a very slow turnover of the total surfactant PC palmitate pool. The novel and safe method described in this report could be applied to address many important issues concerning surfactant metabolism in preterm infants, children, and adults.

Acknowledgment: The writers thank Janine den Ouden and Ingrid H. T. Luijendijk, Erasmus University Rotterdam, Rotterdam, Department of Pediat- 
rics, for excellent technical assistance; and the nursing staff, residents, and neonatologists for their help and support with this study.

\section{References}

1. A very, M. E ., and J. M ead. 1959. Surface properties in relation to atelectasis and hyaline membrane disease. A m. J. D is. Child. 97:517-523.

2. NIH Concensus Conference. 1995. Effect of corticosteroids for fetal maturation on perinatal outcomes. J.A .M .A . 273:413-417.

3. J obe, A. H. 1993. Pulmonary surfactant therapy. N. Engl. J. Med. 328: 861-868.

4. Hallman, M ., T. A . M erritt, M . Pohjavouri, and L. G luck. 1986. E ffect of surfactant substitution on lung effluent phospholipid in respiratory distress syndrome: evaluation of surfactant phospholipid turnover, pool size, and the relationship to severity of respiratory failure. Pediatr. Res. 20:1228-1235.

5. H allman, M ., T. A . M erritt, T. A kino, and K. B ry. 1991. Surfactant protein $A$, phosphatidylcholine, and surfactant inhibitors in epithelial lining fluid: correlations with surface activity, severity of respitory distress syndrome, and outcome in small premature infants. A m. Rev. Respir. Dis. 144:1376-1384.

6. J obe, A . H ., M. Ikegami, S. R. Seidner, S. Pettenazzo, and L. R uffini. 1989. Surfactant phosphatidylcholine metabolism and surfactant function in preterm, ventilated lambs. A m. Rev. Respir. D is. 139:352-359.

7. Jacobs, H., A. H. J obe, M. I kegami, and D. Conaway. 1983. The significance of reutilization of surfactant phosphatidylcholine. J. B iol. Chem. 258:4156-4165.

8. Ikegami, M., A. H. Jobe, T. Y amada, A. Priestly, L. R uffini, and E. Rider. 1989. Surfactant metabolism in surfactant-treated preterm ventilated lambs. J. A ppl. Physiol. 67:429-437.

9. J acobs, H., A. H. J obe, M. I kegami, and S. J ones. 1982. Surfactant phosphatidylcholine source, fluxes, and turnover times in 3-day-old, 10day-old, and adult rabbits. J. B iol. Chem. 257:1805-1810.

10. Magoon, M. W., J. R. W right, A . B arritussio, M. C. Williams, J. Goerke, B. J. Benson, R. L. H amilton, and J. A . Clements. 1983. Subfractionation of lung surfactant: implications for metabolism and surface activity. B iochim. Biophys. A cta 750:18-31.

11. Bligh, E. G., and W. J. D yer. 1959. A rapid method of total lipid extraction and purification. Can. J. Biochem. Physiol. 37:911-917.

12. Touchstone, J. C., J. C. Chen, and K. M. B eaver. 1979. I mproved separation of phospholipids in thin layer chromatography. L ipids 15:61-62.

13. Christie, W. W. 1989. The analysis of fatty acids. In $\mathrm{G}$ as Chromatography and Lipids. A Practical Guide. The O il Press, Scotland. 64-84.

14. Folch, J., M. Lees, and G. H. Stanley. 1957. A simple method for the isolation and purification of total lipids from animal tissues. J. Biol. Chem. 226:497-509.

15. Pfaffenberger, C. D., J. Szafranek, M. G. H orning, and E. C. Horning. 1975. G as chromatographic determination of polyols and aldoses in human urine as polyacetates and aldonitrile polyacetates. A nal. Biochem. 63:501-512.

16. Carnielli, V. P., E. J. Sulkers, C. M oretti, J. L. D. Wattimena, J. B. van Goudoever, H. J. D egenhart, F. Z acchello, and P. J. J. Sauer. 1994. Conversion of octanoic acid into long-chain saturated fatty acids in premature infants fed a formula containing medium-chain triglycerides. Metabolism 43:1287-1292.

17. Ballmer, P. E., A . M cNurlan, E. M ilne, S. D. Heys, V. Buchan, A . G . Calder, and P. J. G arlick. 1990. M easurement of albumin synthesis in humans: a new approach employing stable isotopes. A m. J. Physiol. 259:E 797-E 803.

18. Wolfe, R. R . 1992. Protein synthesis and breakdown. In R adioactive and Stable Isotope Tracers in Biomedicine. Wiley-L iss, N ew Y ork, N.Y. 377-416.

19. I kegami, M., A . H. J obe, and P. W. Nathanielz. 1981. The labeling of pulmonary surfactant phosphatidylcholine in newborn and adult sheep. Exp. L ung Res. 2: 197-206.

20. Jobe, A ., M. I kegami, I. Sarton-M iller, and L. B arajas. 1980. Surfactant metabolism of newborn lamb lungs in vivo. J. A ppl. Physiol. 49:10911098.

21. G latz, T., M . Ikegami, and A. H . J obe. 1982. M etabolism of exogenously administered natural surfactant in the newborn lamb. Pediatr. Res. 16: 711-715.

22. Jobe, A ., E. K irkpatrik, and L. G luck. 1978. Lecithin appearance and apparent biologic half-life in term newborn rabbit lung. Pediatr. Res. 12: 669-675.

23. Henry, M., M. Ikegami, T. U eda, and A. H . J obe. 1996. Surfactant protein B metabolism in newborn rabbits. Biochim. Biophys. A cta 1300: 97-102.

24. A dams, F. H., T. Fujiwara, G . C. E mmannouilides, and N. R äihä. 1970. L ung phospholipids of human fetuses and infants with and without hyaline membrane disease. J. Pediatr. 77:833-841.

25. Jackson, J. C., S. Palmer, and W. E. Truog. 1986. Surfactant quantity and composition during recovery from hyaline membrane disease. P ediatr. Res. 20:1243-1247.

26. M aniscalco, W. M., J. N. Finkelstein, and A. N. Parkhurst. 1983. De novo fatty acid synthesis by freshly isolated alveolar type II epithelial cells. Biochim. Biophys. A cta 751:462-469.

27. B atenburg, J. J., W. J. L ongmore, and L. M. G. V an Golde. 1978. The synthesis of phosphatidylcholine by adult rat lung alveolar type II cells in primary culture. Biochim. Biophys. A cta 529:160-170.

28. Carlson, K. S., P. D avies, B. T. Smith, and M . Post. 1987. Temporal linkage of glycogen and saturated phosphatidylcholine in fetal type II cells. Pediatr. Res. 22:79-82.

29. Sauer, P. J. J., V. P. Carnielli, E. J. Sulkers, and J. B. V an G oudoever. 1994. Substrate utilization during the first week of life. A cta Paediatr. 405(Suppl.):49-53. 